か简る亩

法こ後の方倠有、修を上

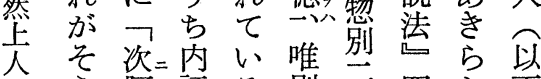

飞 5 阿証る别功四吕市

特で彌と。説, 锶七に敬

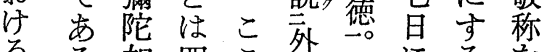

るる如四こ角，先、にるを

戛来, 智で功物”

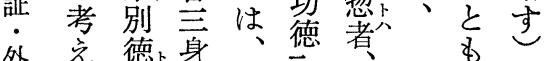

尔点者等佁也点四含は

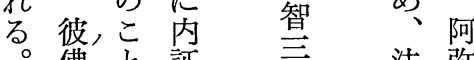

法 弥

ま有で・身然陀

厓公古外等然仏

文萬り、角德説㤂

脈眾諸心另安仏

か相仏公一容变

判想飞総切, 切説

断其, 心㔔諸文守

す中

る以平功留 みの

に皇等德等, よに

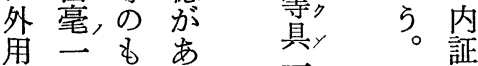

相尔合 - 証

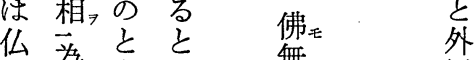

の為さし無用

個最机た異它

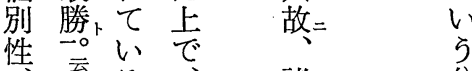

特云去。総墥, 分

盖

殊之外 II 中= 窟

性 W用内説 $=$ 用

根

示説泟佛, 立

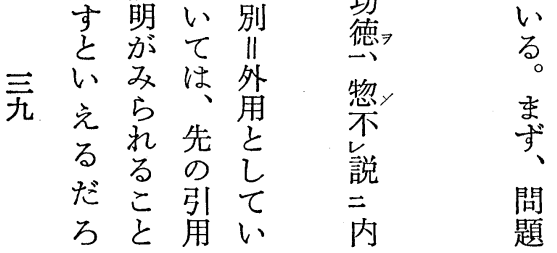

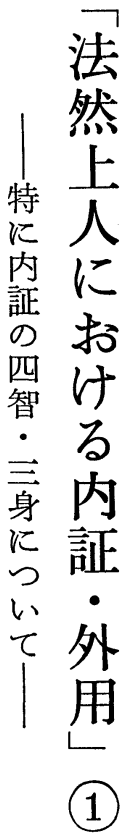

宣

雄 


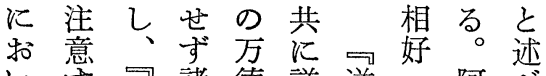

心す包諸德詳逆・阿心各切初選亏尔用証仏内

て ゙選仏所し修光弥 5 守几内勝択こととは容 阿き热飞帰く説明陀れ三証, 劣下集とはは内を

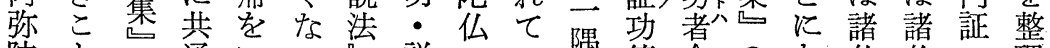
陀亡の通Wっ説のい隅徳念のな仏仏・理 仏で方导うてで法功る是习相佛第るの伀名 にあ方をた内徳。以好是言。特特用る

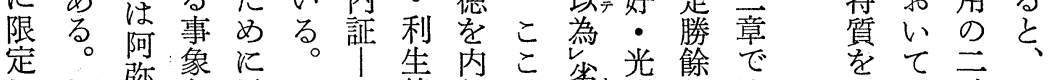

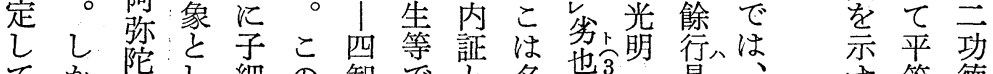
てか佁し細の智で 名边。是、、方等徳

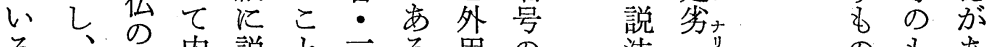
る、名内説之三る用の法所”问

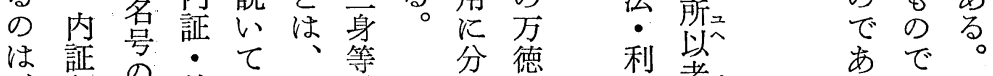

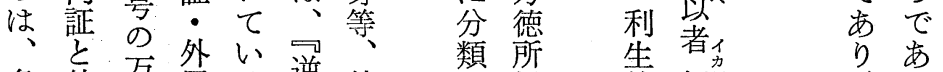

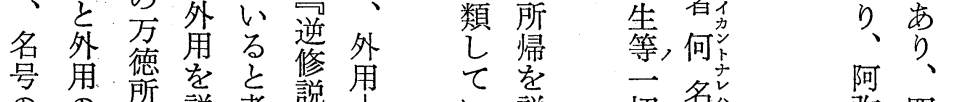

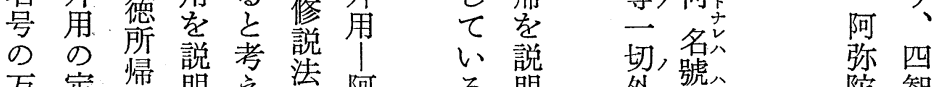

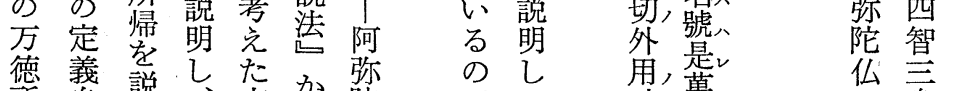

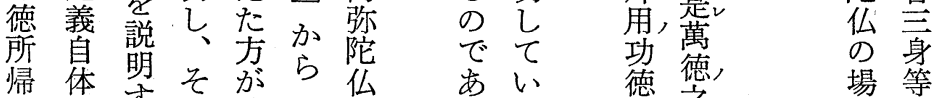

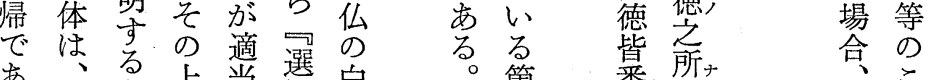

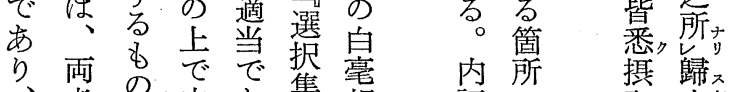

内者で内集相 内証括市証方へ充 - wり、諸。思て 外て阿品ま思い想い 用同弥苹た等る 变こ

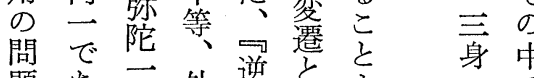
題交仏外逆焂占

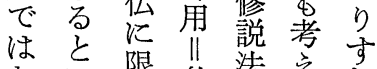
ない搌仏造点机

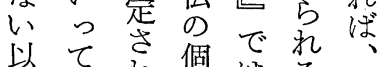
上よ热别はる氞 再い者論性阿热択 者だ理と弥哭集 柔ら。古て陀热は 選点帒集莴

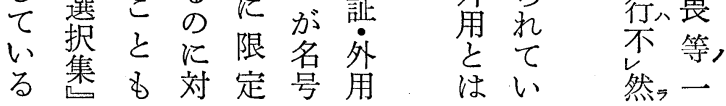
証 で と要 性古

阿”然 四古皇票 智、㖸, 彌 想

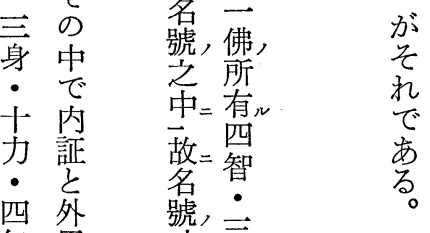




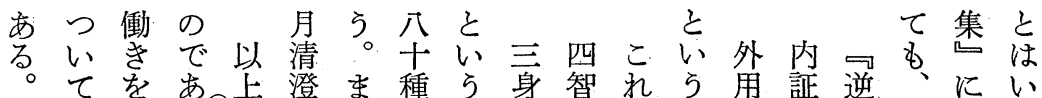

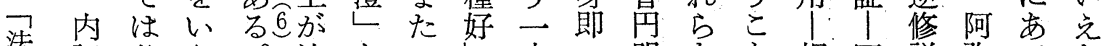
然証仏 万。法と

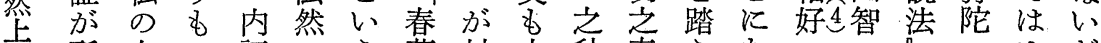

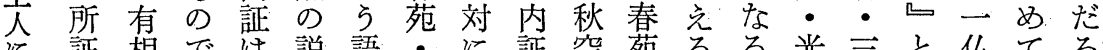
に証相では説語・に証空苑るる光引と仏てろ

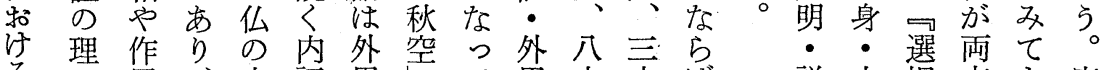

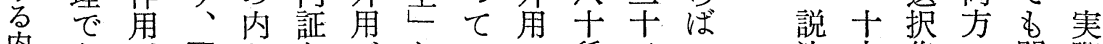

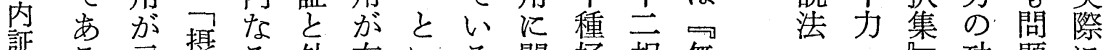
証る示㷦る外有いる。関好相無・准功題に

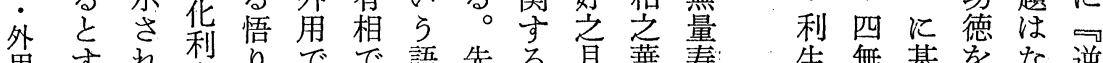
用すれ梨りでで語先る角華寿: 生無基をな逆

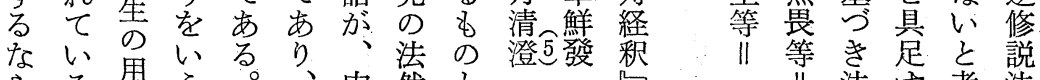

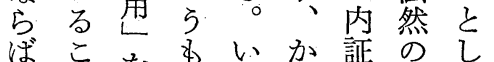

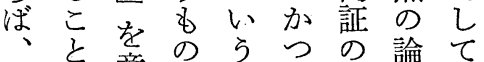
そょ意で委清静理捉 こり夺市で浄的に党

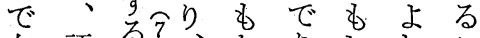

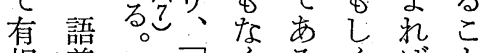

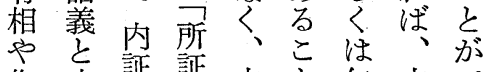
作内証証内京無内で 用容外理証学相証き をは多理。表性とる 想一用外現の外だ 定致語意用し比用 さ尔語意とて喻㤎う。 せる義禁いいで対。

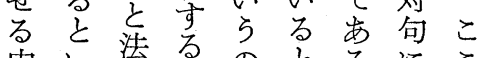
内然るのとるにこ 容光然こはいとなで がる説れ、党受っは

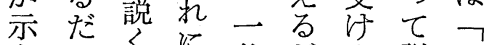
さろ治皆説四

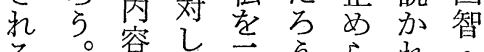
る。容元云方。机

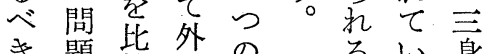
き題踥角の視方身 でと整角視: のる 即 はなと点注と一 なるた対いし

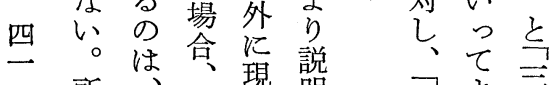
所内外瑟盟華㣰

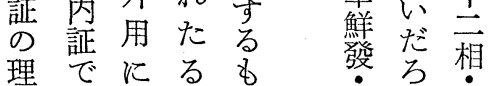

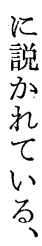

個仏説々冯説 别平等内変る。杂 証

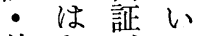
外な㤎当 用い墸内 整で泛証 理步平 II 亭る。等楛 な 8 平 占等 あ外 り 用 外仏 用 の 分 個 仏別 の 性 個 別 心 的 5

な 概

b 念 のを

で㷷 択 


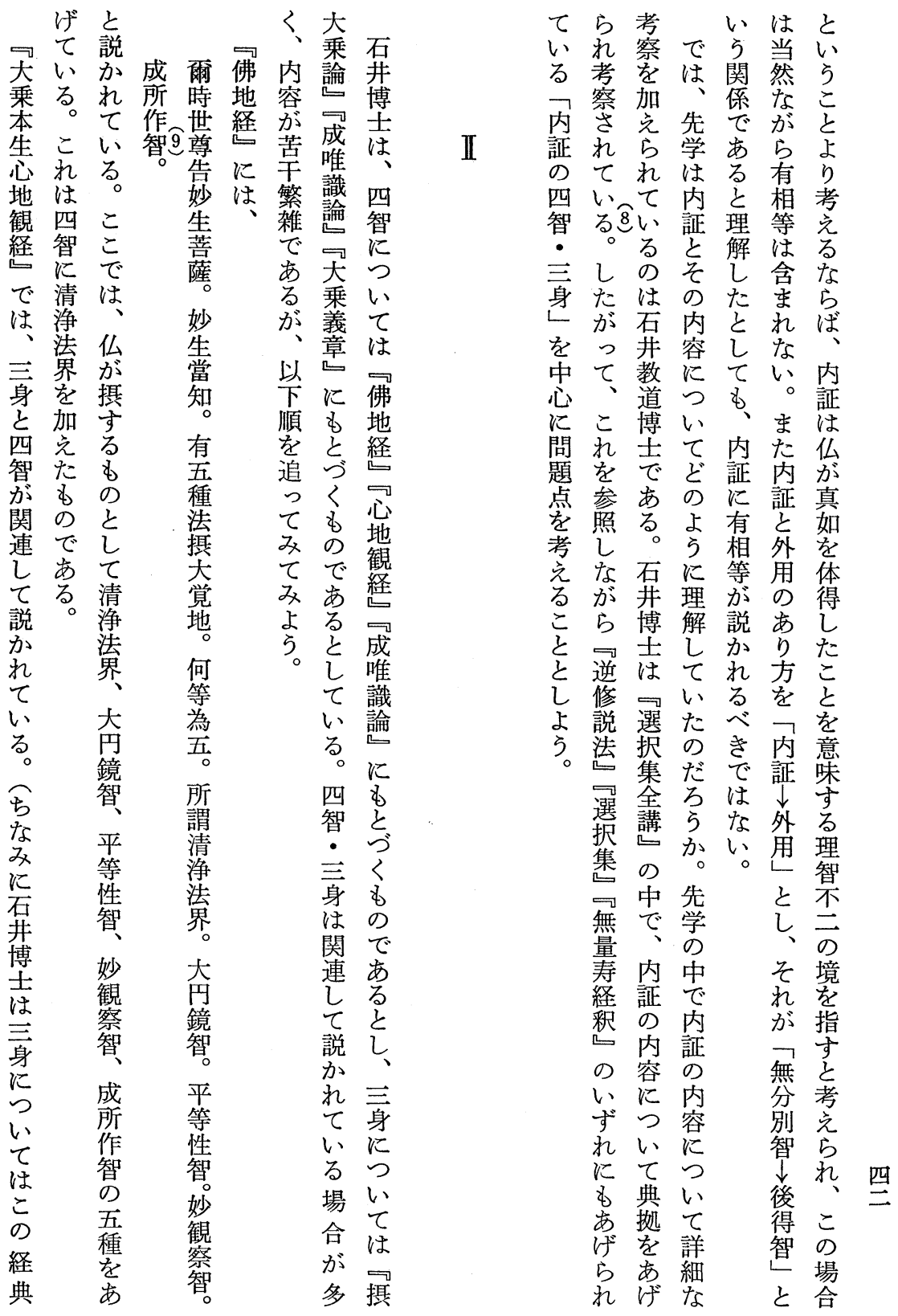




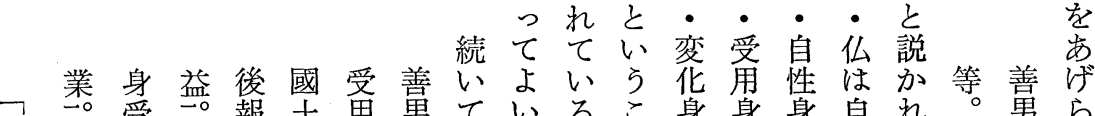
法 0 受 0 報土角男ているこ身身身自れ是男ら

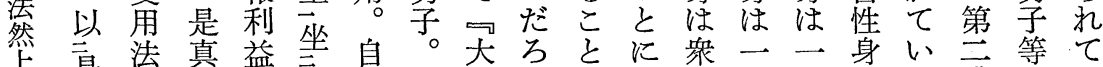

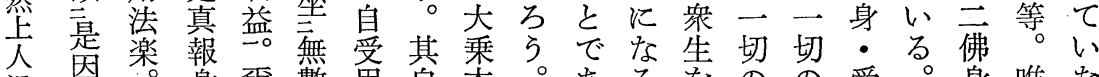
に縁。身爾數用自本。あるを的の受。身唯な 特縁一有時量身性生方。度智煩角内有二小

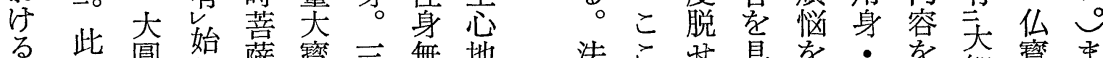

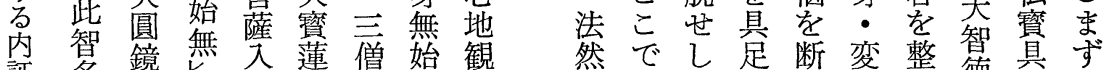

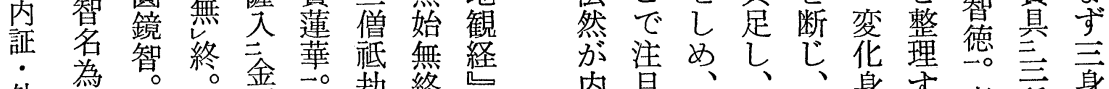

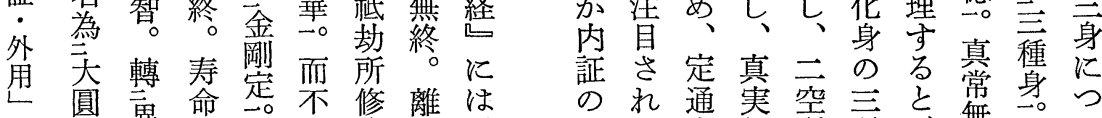
鏡 䔬 命劫断可蓄离 智熟 數断説行 切

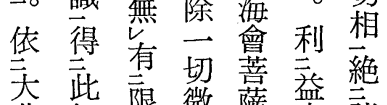
悲智 限微 薩 恶諸 故慧量約後楽戲 恒如初知圄諸論。

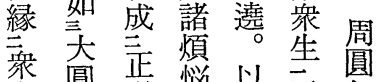
生。鏡 覚障 严恶無 依現窮澄垢十泪疑 言藷證繪地然 智色来得罊満常

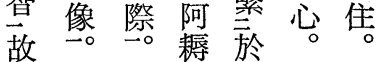
常 如諸多頂運其 如是 根羅上。身受 法如 相蓄供直 身 性。来好藐供養身。 雙智 周萻恭色 有

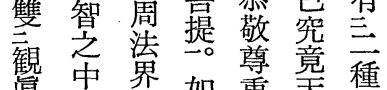
觀 中。界 如尊 竟 種 俗 能 四是 䝷 知 出

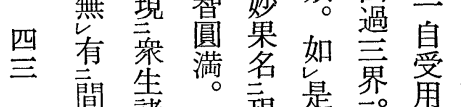
間 生 㵔 名 是 界 買 断 善 是 報 名 浄二 常悪報利䨿妙陀

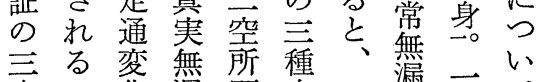

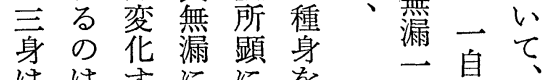
ははすをにを切性 諸自ここして具足諸身 集貹亡 云 等身 二 切切 る 悉 学

あ゙受妐諸諸。 る角同皆皆 之身事同平 て 変 む゙意等 る身。る る そ 妾 考が

え 諸 る 仏 之、括

こ い

之平

自 等

体・

は同

意

共意

通同

る 事

第 変
华
佛 身
身
有 第

有第

恩徳 㤫

定 大

通 断

變 德

現 $\rightarrow$

切 空

諸 所

佁 顯

皆切

同諸 事10佛 悉 々 皆 平 
自受自 説

受角性吕妙无諸善利用萬門薩楽用業得是能

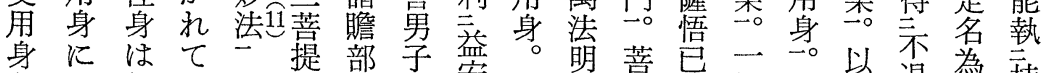
身に はて

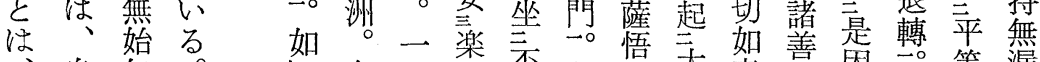

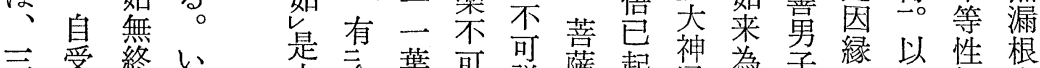

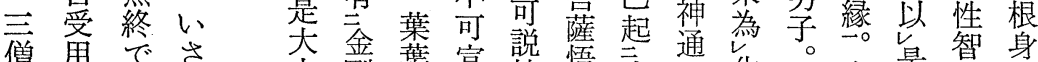

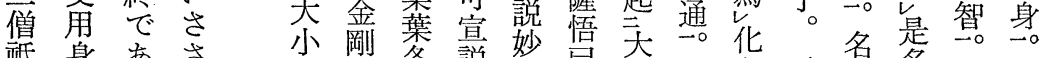

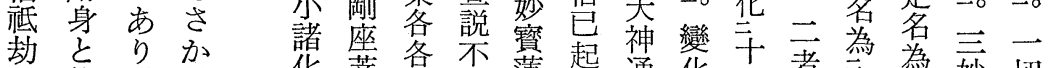
に他、長、化菩為可蓮起通华地者成斉妙切

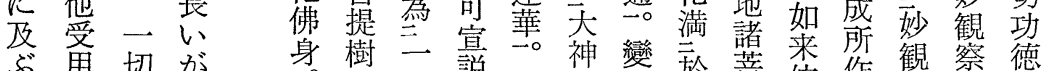

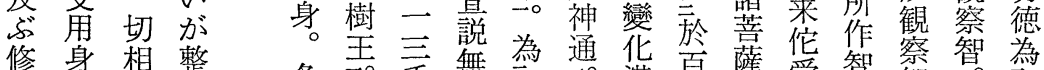
修身相整 各王手無煘通华百薩受智察智為

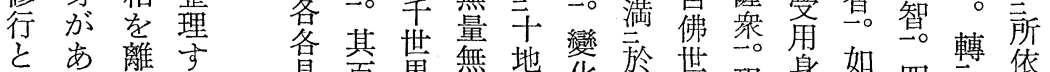

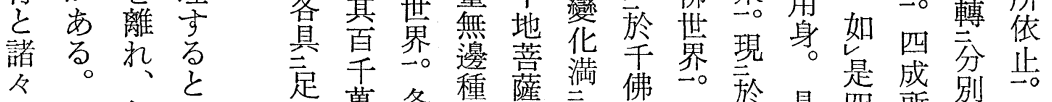

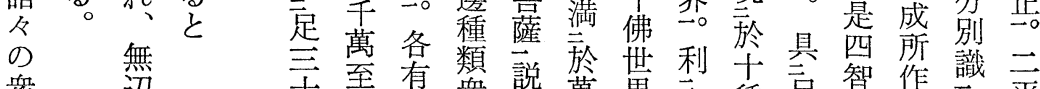

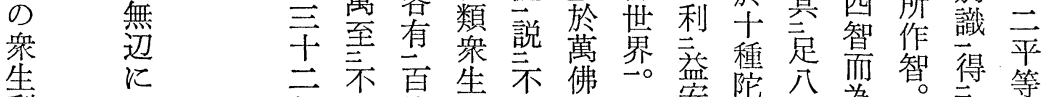

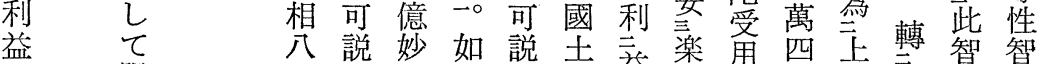

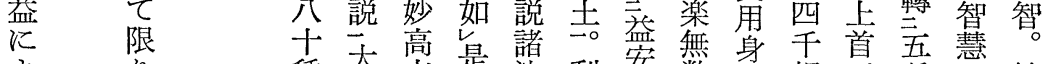
よ

七 $\stackrel{1}{<}$

菩常

薩集 乼

十市

地满年

心

金

岡

定

入

切

の

所

知

障 種大少是諸利晏無身 千首五慧

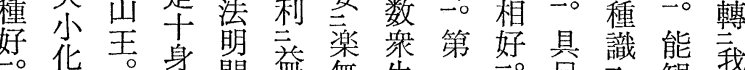
為佛正皆管無生。元。足識能 我

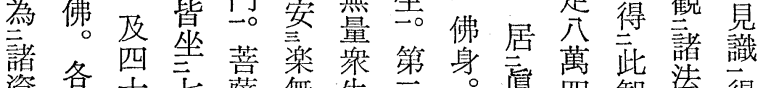
資各十七薩無生言。德四智法得 粮於洲寶悟 数二。佛坐浄采慧息相此

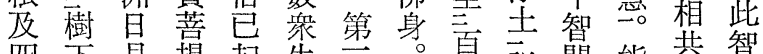
四下月提起生言。葉説門能共智

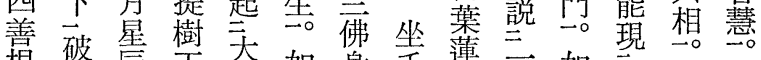

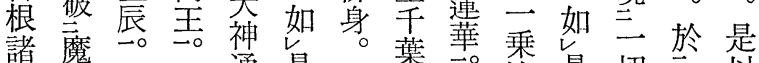
菩廆三證通是坐蓮为法是切蒵以

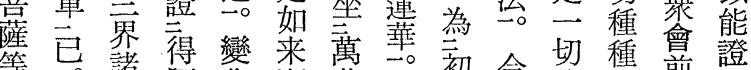

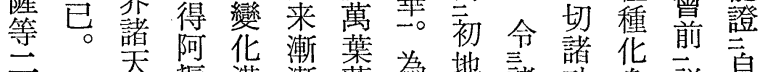

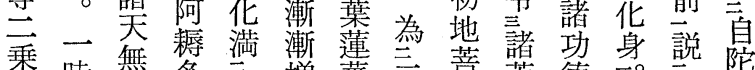

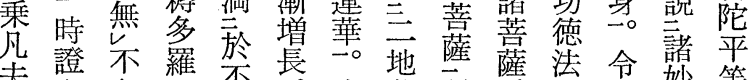

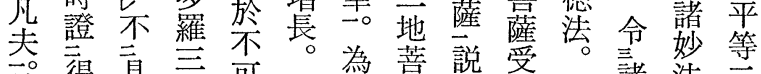

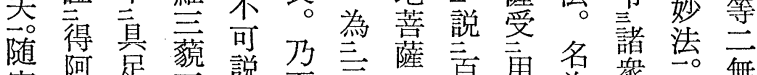

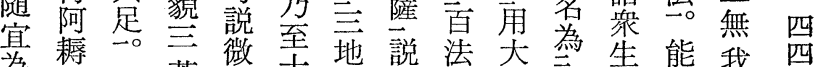

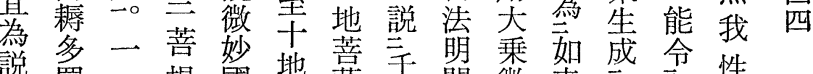

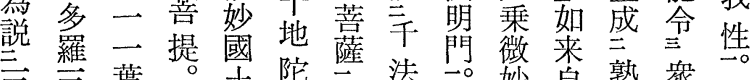

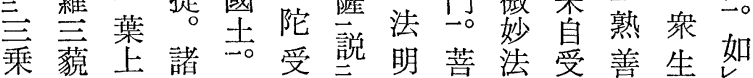


身き内陀受か用之

方換証仏角和身いた変二る他こ成妙平大煩 八光 法万仏考中心自こに身の 角ら作察性鏡障 然四す の党、る受之機に如 身の智智智智を 然千論内る自こ用に根は来主四と充立断

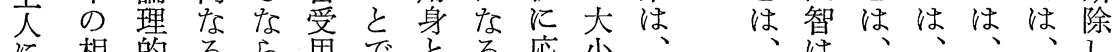
に相的るら角でとる応小、、は 持好飞悟ば身あ他。じ古十八五分我阿た けを無り、をる受四てあ地方種別見頼こ 学有理素内再智法り、の 四四識識識耶衣

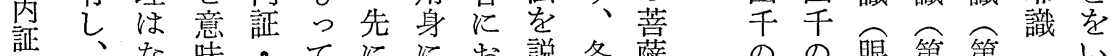
外有以守外真触分けく之年第

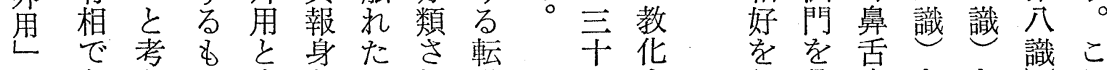

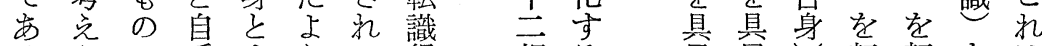
るらで受すうて得相る 足足る 転転を梳

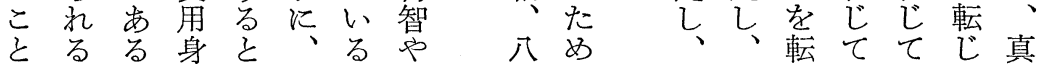
はのが・い法こ四十に真自己゙得得て報 外で、他 ら然之智種十 浄受て らら得身 用あ種受、のとの好種土用得れれらで

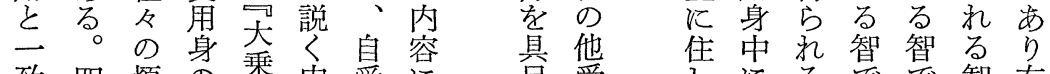
致四煩の本内受に足受滛有

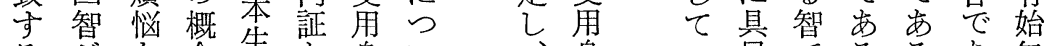

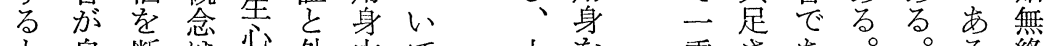

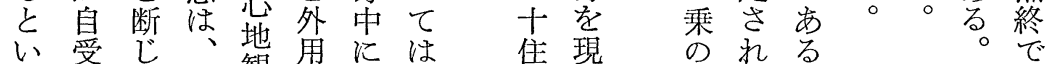

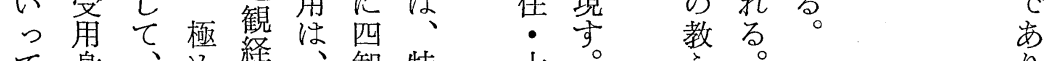

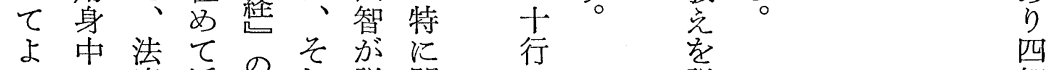
いに楽近所祘問 だ説をい所染か題 ろ加受的説れ机 万。れ角の学四な こいた年智他い 机れこる直仏用あ らばをという身ら

のなをいて、相中ら こ扰意爷受恏父注

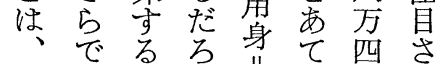
四法市自ら弨は千和 五然る受。報めのる 加。角つ身て相の 内他身ま 11 好 内他身 ま 阿 る 好

説

十

向

及

四

善

根

の

菩

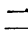

垂

夫

天

乗

妙

の

法

受

せ

L 智 留 满 $\begin{array}{ll}\text { 莘 } & \text { で } \\ \text { 薩 } & \text { る } \\ \text { た } & \text { る }\end{array}$

大

用 
平 9 大 説

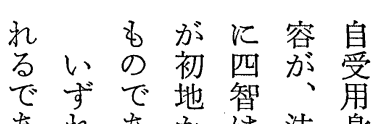

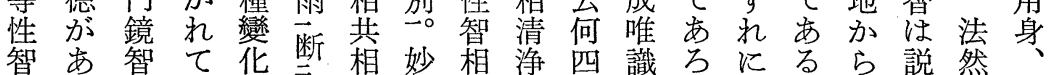

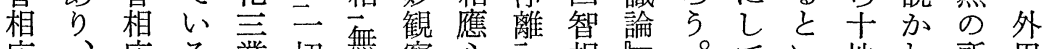

応、応る業切舞察定諸相边。てい地れ所用

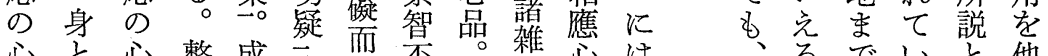

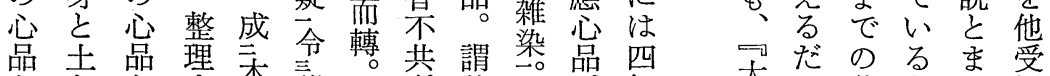

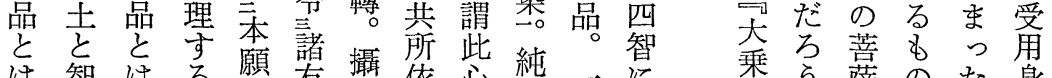

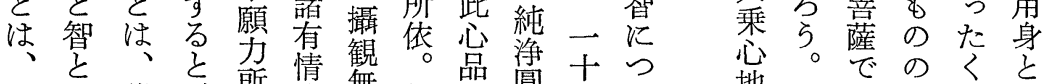

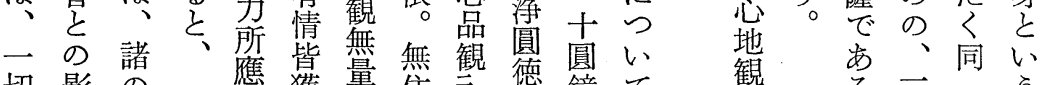

切影の 鷹 獲 量 篗觀德鏡て 観 る

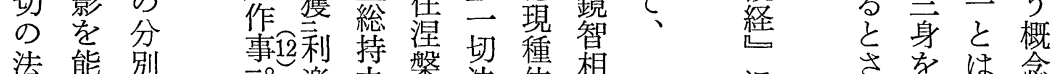

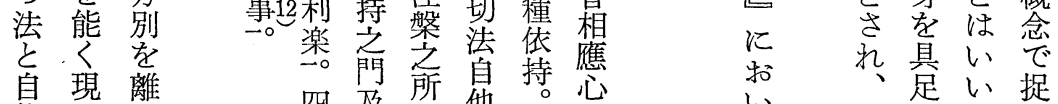

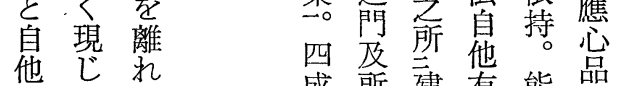

他じれ尔成立建有能品

有能境所 発立。情現謂

情々要智生一皆生此

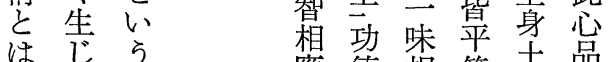

はじ。應德相等 智離

悉 。性

字

点寶霣大影諸

皆相

等 清

謂於来慈無分

謂 於 来韮簡 別

心䀽祭恒 無 所

な 浄

観斻

覒㝟諸

る の

境 雑

を染

小学

5 離

諸㢳

の い

有情 る

の純

求

め浄

に応市

品會 三共断縁

為曾 妙相笨行

欲能 観 應 窥 相

利惒察隨来細

楽 矏 相 諸 祭 難

諸作應 有 如 知

有青盖品所复不

故別謂楽圓 妄

故 皆謂 示 鏡 案

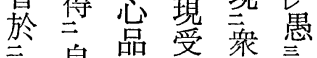

古臬学色

方在。䚑 身像切

示雨諸圭一。境

現大法像平相

¿ c

種 法自差等 性

七 凡守が党

内 のといw

証教い。た

外㤎らすず能

用 変 5 、性

花 身記然学

受记述はし

用 限は内て

身 定 み 証い

他沓层立

息いなな孫

受る。具よ

の 点さ足ら。

類 ぞにるた

似性は㤝をだ

が 法他りし、

指㸃受て 他

で 思身る 角藉

る 思身 る

点 愁教方地 四

点相华自経 六

目尔対身の

さ W象中内 
严説含題智要智と成の妙て 受諸無平相所大㣔な内。差う所作観

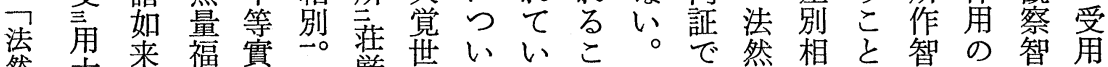
然大来福實—㛜尊いいこ で然相と智の智角 上乗由慧性一尊てるとしあのをに相差相の 飞法平資師貹故成或四に知にり、告な応别応身 拉楽等所此身體就唯智る後証る。心現心土 讨智所自。依無識方成の智こ品し嵒々 る合示起性謂聚卡論法で唯严四をれとるとの 証些現無亦諸義督然あ識智智指にはた影

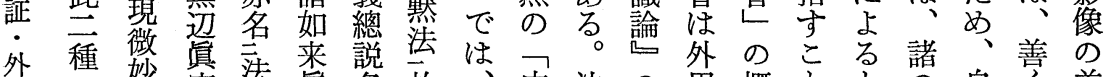

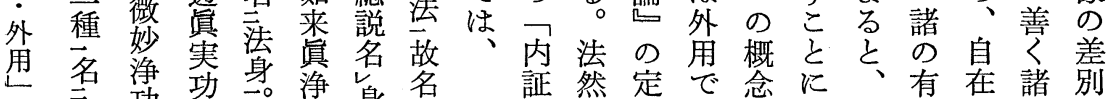

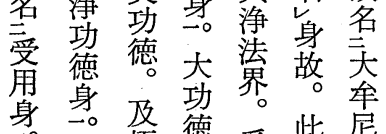
三居賲德受些䲩 變純浄所變身些 維浄常歨华法虐

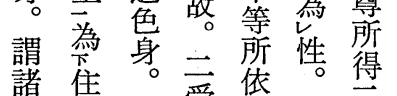

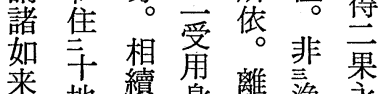
来地續身離浄永 成諸然。相法離

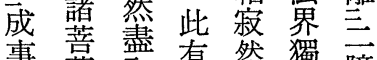

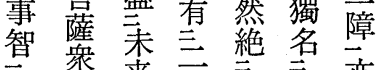
鶖筑来種諸法孪

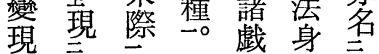
無天恒一論。法

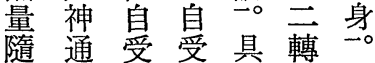
類轉㛚角無俈無

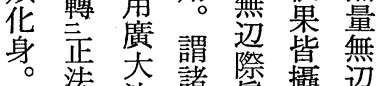
法攝边 居輪薬㛎裳故力

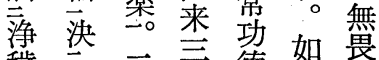

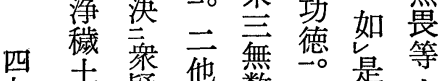
舞他数是法大 為網受劫是身功 末令用修切直德 登被謂集法至法

証然定で念飞有在諸别 のが義西衣な情で法を 四、饵る比る円を西の示 智成文䡆。鏡教る自現 唯法ししっ智炛。相守 と識然てた类性声 で論のい場り、共。 は説た合、架た相 一をな性めを 致参当占藏籍

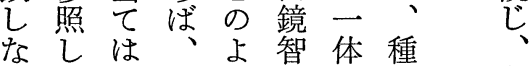

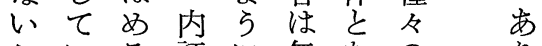
こいる証飞無なの方

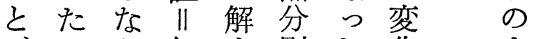
加加無打别华 指ど将分る智智三专 摘 5 别かでを丵を で加内智非古い娄洞 性証常员、示察 万別の外飞、现宗 挖火中用困後平しる 万乙飞 11 難 等本境

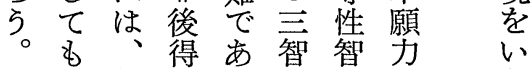
代無智方。星昆 表別全今得観文大 的智方仮智察方襌 な元飞智导 唯後飞、仏会

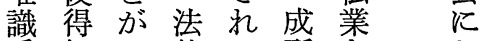
系智で然て所括 ののき分い作現い

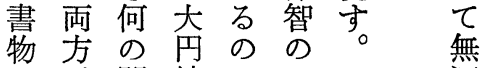
化問鏡で三边 
有安学触々機変の他際自文法二仏法牟説 等証る氺らに化た受限受つ身つ果身尼か地 がの場たこ順身め角な角にとにとと尊れ諸 説 三合法とっとに身く身はもはしいのて菩 か身然にては広と受い自てら所い薩 机志のな教、教は大性角う。性のの得る。衆

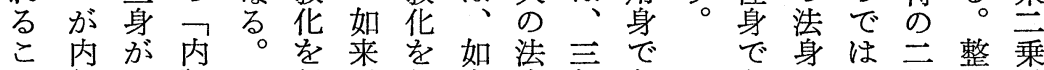
と証一証こ行が行来楽無市安は果理異

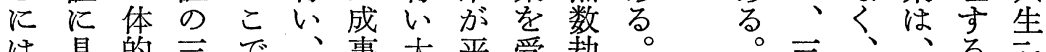

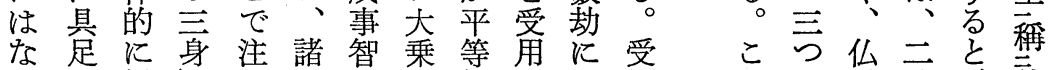

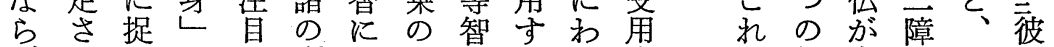
ずれ觉さ利よ法にるた身は相真よ機 矛たら考机楽っをよ。っに受別如り宜 盾悟水光るをて受ってい はりてるの得変角て 無自 消をい上は世現せ示量受 隇意るで、しさし現

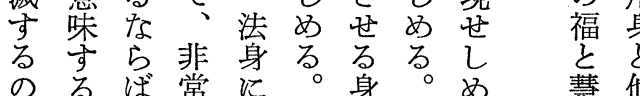
のるば常に。身。め慧他

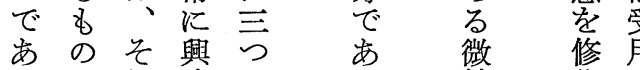
るで机の喿の妙集身 あを深相 り、法身别

ᄂ $と$ の かしでる

むて あ 々解る

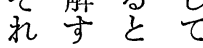

蛙当 法根党身 身扰了零

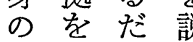
意示方訬

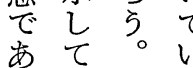
当なる とるぜさ

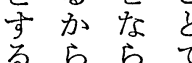
な无壮 要娄。 织。夜 内法息串 証然説 飞の明先

\section{浄 哖}

穢德 真 る

に 身 の

居で

乙 あ

?

未純

登

地

の

菩

粒

产

乗

異

生

た

ぬ

以
の

しが

功

德

c.

円

浄 か

土 $\quad$

V 浄

居证

乙 常

十色

に它

隹 䙳

す る

諸末

蔁来
用が

之あ同机

変る华六

之市 る

平 $っ$ の

等たで

のこ法

所文身

依每之

で法い

あ 身ら。

相

離

枳

諸

戯

䜗

絶

完

光

こ

の

筫
現

通

説

法 令 各 獲 得 利 楽 13 


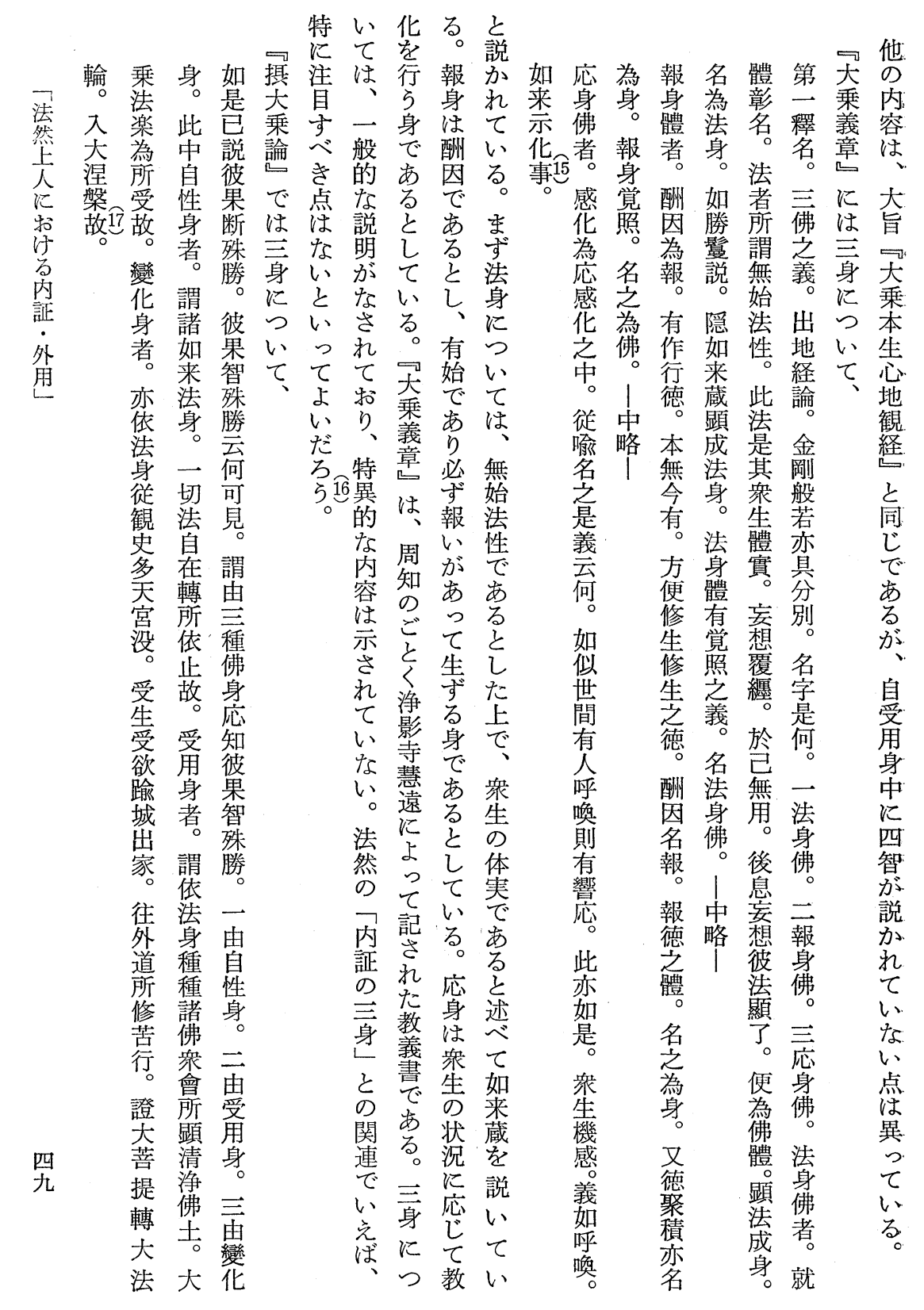




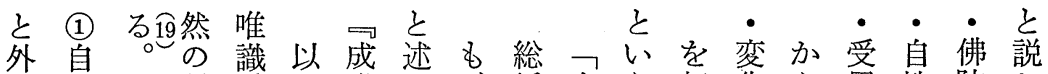
用性た説絮上唯袋、括自亏転花ら角性陀か に身だくの識ら法し性こじ身受身身のれ

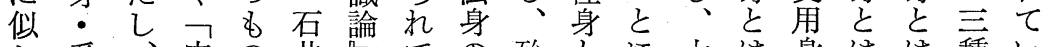
加受、内の并少ての殆とに大は身はは種い よ用そ証で博のい名炎いな涅法と法い仏る。 っ身れのあ土中るの単らる槃身い身わ躬 て い変れ智。指みこに仏は長入と理 る华の

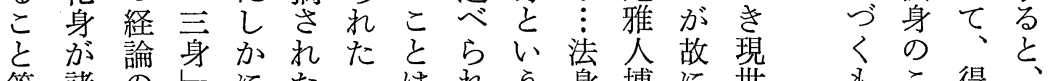

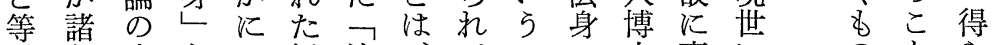
が仏中と马経法、てのの土変に无ら 指にで合四論身法いとこ住現ででれ

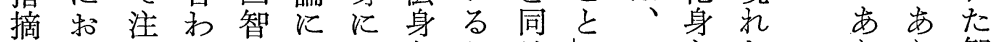

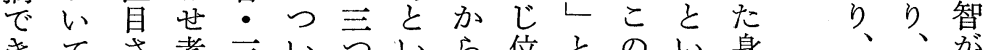
るて平 阮光身 て 。等るた考相語あ意 ら分。市仏切ぐ

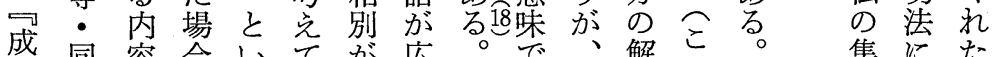
成同容合いてが広。で、解こ集にた

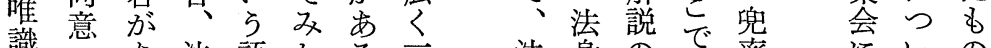
識意あ法語たる方法身ので率にいの

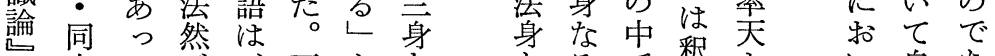
事たが、石とををるで釈よ自あ び ここ全唯井心含名語、尊り方在る

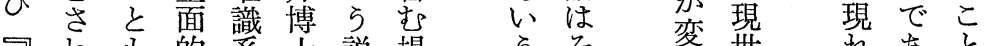

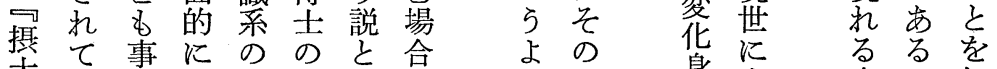
大 、実々経指同㤎方意方生身こ知

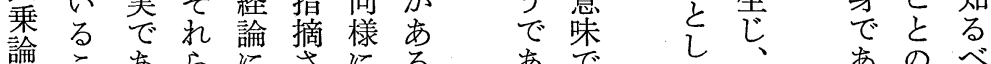

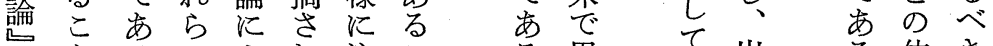
でと、る に

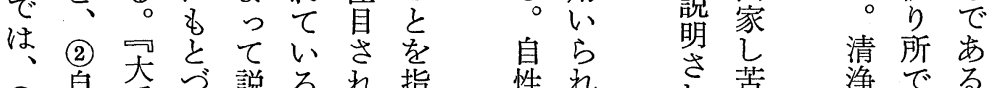

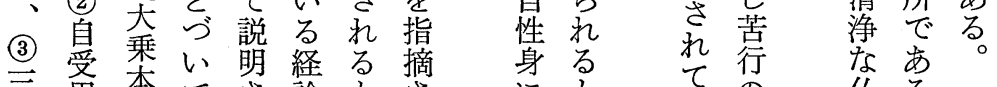

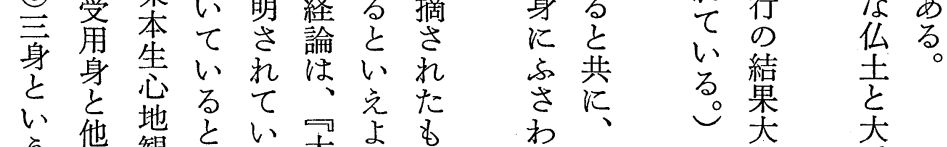

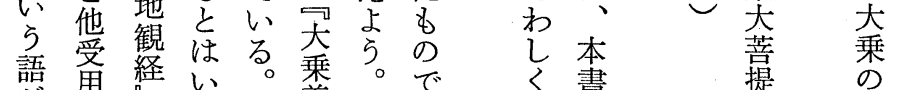

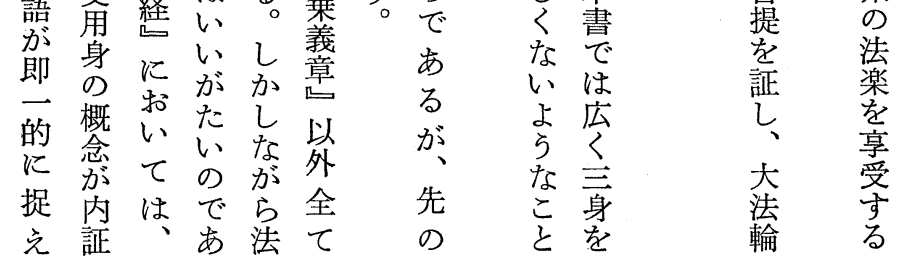


な及

いび法

か 三 然

法之身の

然 い説

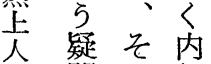

に問の証

拉が中・

け生飞外

るじ有用

証た相の

外さ作 ち

用 5 用

に 等 特

はをに

、含問

一导題

仏こ文

を造

説少て

明 考

寸 充

了新 5

場梊机

合生た

の理

射些

論岂あ゙内

がる証

報証説

のの茂

点にる

説四

智

よ扭。

て る

体䒚で

相 文

甬矛。

五示盾た

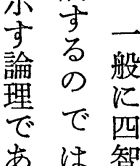

のこをらつてににに根ら でら言ば雖内よまな捉近拠れ あしい、爾証ったる兊いと法 り、て表法為需て、法だ法むな身 同るた然善身法知引射がるの

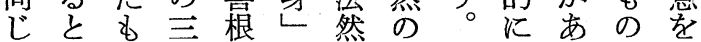
く法の身成の然至解るで表 ᄀ然で同就, 解三身釈と市す 射の体一釈身論吉いる。

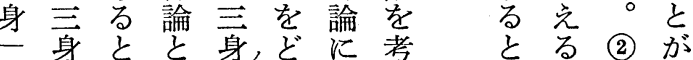
の別いは功のは尝いだはあ

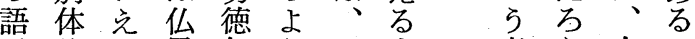

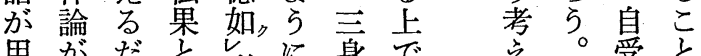

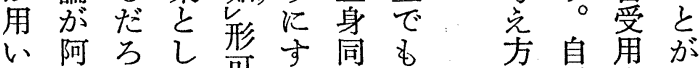
ら弥 5 可方体こ受身あ れ陀。内奉少論れ㐫角中淿

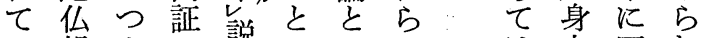

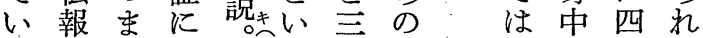
る身り具比方身こ如智る

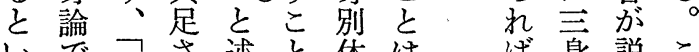
いで呙さ述と体は将身説こ

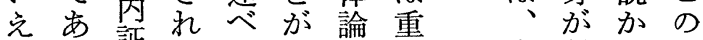
どる証たて重施重、内婹机ら

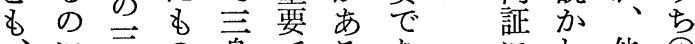

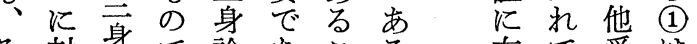
そ対身で論要学有て受は のし々古にる方。相い角、

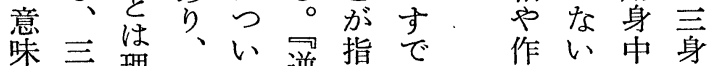
内身理そて逆摘に角点に㤎 容同智れ語修さ石等㤎相諸 は体不自っ説れ开問好仏 大論严体て法て教含題がに きと蛋はい四い道委で説和 くは示仏る四る吻博机あかい

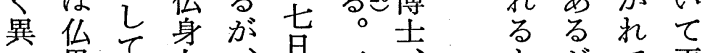

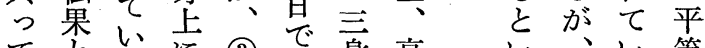

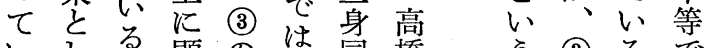
いしる顕の内同橋 5 (3) るで るて考琴る内証体弘問のこあ 之の考其う証論次題よ方る 心内爷な外を博点 $う を と$

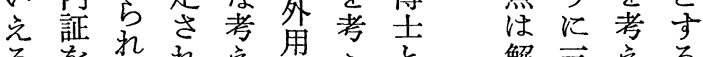

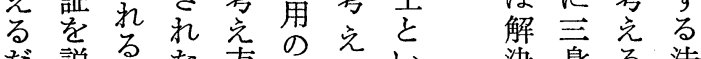
だ説るた方説るい決身る法 ろ莳で真に説る場た 卞をと然

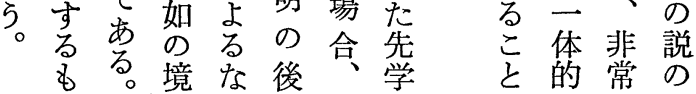




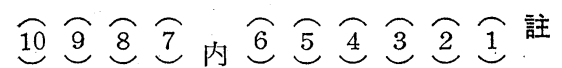

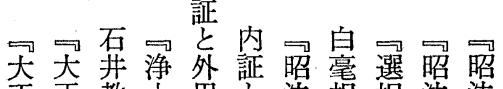

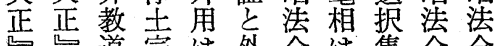

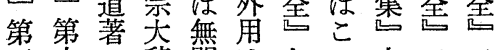

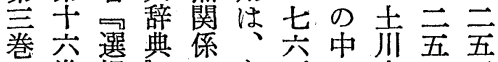

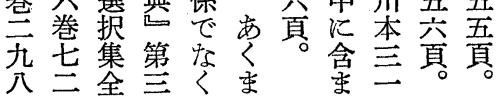

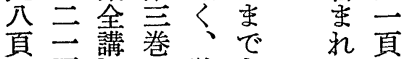

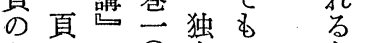
。交无 $\mathrm{O}$ 竞仏栲

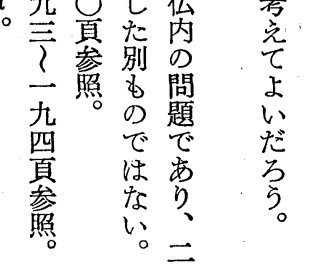

が

成

就

e

热

隹

3

か

b

究

仙

灾

乌

る

の

で

あ

そ

意

禁

は
考いは三びるる

完々め身口四之の らいる唯智いに

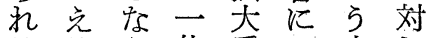
るるら体乗つ内六 の゙艺济的諭容内 あら。法捉には告証 。っ 然占口可外 玉説氺て大垂う用 りくた二乗に架 法内合的生释 仏 然証法守 はの仏法地べ筧 合四智理の経きか 証 ・智意飞が視 の三柰它华問点 四身云息題点 智しのて受でり - は境捉角方説 三仏学壳躬っ明

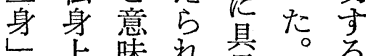
走禁势悬。当

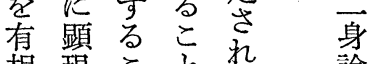
相钼气衣势馀

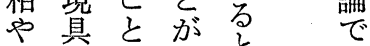
作是的示衣西 用要要步方

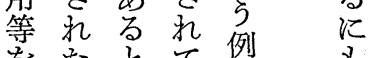

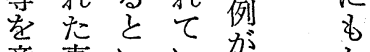
意真心多㔔 味如 5 た要少

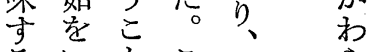

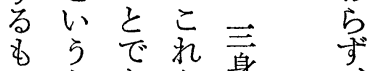

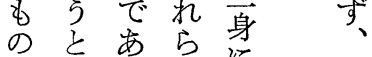

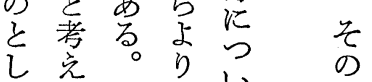

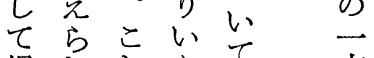

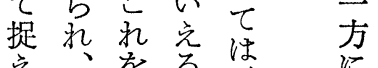

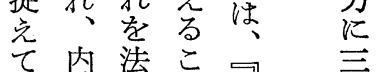

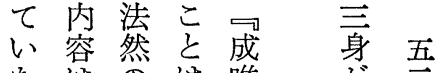
小性第泩唯务 加矛説、識具

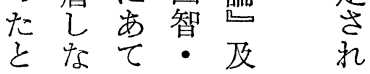




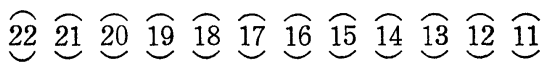

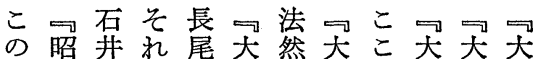

よ法教皆雅正の正で正正正

う全道れ人説心い心江

な渚の著第々第 う第第第

点三四経司内四法至严

か五浄論掑十容十身十十巻

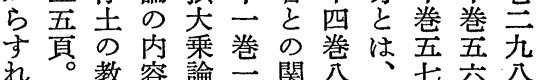

証

外

用

ば義が速連当当頁頁

内 $\quad$ 共杂は七然の无の

内証 教致严頁な頁な

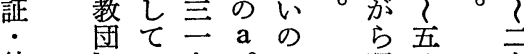

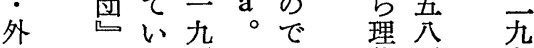

用のな頁は体頁杂

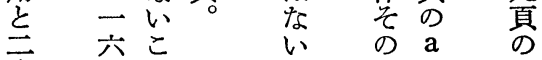

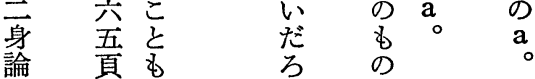

に忘

つびれ

い 高て

七 橋

考垒な

爷瓷な

必可以

要法だ

が然ら

あ 浄 5。

だ䖍

ら分諸

別題

ろ

の 题

機 七

論公公

か な

石仏

博身

志比

何顕

故 現

典具

さ

た法

の 身

否盟 る

で四京

五 